\title{
Exploring male and female preferences, male body condition, and pair bonds in the evolution of male sexual aggregation: the case of the Common Quail (Coturnix coturnix)
}

\author{
F. Sardà-Palomera, M. Puigcerver, D. Vinyoles, and J.D. Rodríguez-Teijeiro
}

\begin{abstract}
One of the unresolved problems of male sexual aggregations is that a small number of males monopolize most matings. The Common Quail (Coturnix coturnix (L., 1758)), is a bird species that has a short life span and a reproductive strategy that involves male aggregations, which females visit for the purpose of mating. Once a mate has been chosen, birds leave the aggregation and form pair-bonds until incubation begins. This remarkable mating system might represent an intermediate step between lekking and pair-bond mating systems in which males provide some parental care. We designed a field experiment with funnel traps simulating male groups and single females to observe male and female preferences, and to examine the possible evolutionary process that drives males to aggregate. Radio-tagged individuals were also monitored to study pair-bonding behaviour in the field. Our results suggest that body condition is an important factor in male group formation, and that males with better body condition tend to aggregate, while males in poorer condition wait for extra-pair copulation opportunities. Moreover, this mating system creates a situation in which a queuing strategy might occur.
\end{abstract}

Résumé : Un des problèmes irrésolus des rassemblements sexuels de mâles est qu'un petit nombre de mâles monopolise la plupart des accouplements. La caille des blés (Coturnix coturnix (L., 1758)) est une espèce d'oiseau à faible longévité dont la stratégie reproductive comprend des rassemblements de mâles que les femelles visitent dans le but de s'accoupler. Une fois le partenaire choisi, les oiseaux quittent le rassemblement et forment un lien de couple qui dure jusqu'au début de l'incubation. Ce système d'accouplement remarquable représente peut-être l'étape intermédiaire entre les systèmes d'accouplement avec formation de lek et ceux avec lien de couple dans lesquels le mâle fournit des soins parentaux. Nous avons imaginé une expérience de terrain avec des pièges en entonnoir qui simule des groupes de mâles et des femelles individuelles afin d'observer les préférences des mâles et des femelles et d'étudier les processus évolutifs possibles qui amènent les mâles à se rassembler. Nous avons aussi suivi des individus porteurs d'émetteur radio afin d'observer les comportements reliés à la formation du lien de couple en nature. Nos résultats indiquent que la condition corporelle est un facteur important dans la formation des groupes de mâles et que les mâles en meilleure forme physique tendent à se rassembler, alors que ceux qui sont en moins bonne condition attendent des occasions d'accouplement sans formation de couple. De plus, ce système d'accouplement crée une situation dans laquelle il peut se développer une stratégie de files d'attente.

[Traduit par la Rédaction]

\section{Introduction}

Since the publication of a major review by Emlen and Oring (1977), the ecological factors that have contributed to the evolution of different animal mating systems have been widely studied (e.g., Davies 1991; Arnold and Duvall 1994; Ligon 1999). Much research has focused on birds, which present a wide range of mating systems and intraspecific flexibility (Gowaty 1985; Davies 1991; Ligon 1999).

Among these mating systems, the lek has attracted great interest. Improved knowledge of bird mating systems has considerably increased the number of species identified with lekking behaviour: from 34 species in 1991 (Davies 1991), to 98 species in 1995 (Höglund and Alatalo 1995), and 148 in 2000 (Jiguet et al. 2000).

The main characteristics of a lek are as follows: $(i)$ the absence of direct fitness benefits such as male parental care and pair-bonding; (ii) aggregation of displaying males; (iii) female mating preference based on indirect male benefits (e.g., their genes, safer mating, disease avoidance, incest avoidance); and

Received 27 May 2010. Accepted 25 January 2011. Published at www.nrcresearchpress.com/cjz on 25 March 2011.

F. Sardà-Palomera*, D. Vinyoles, and J.D. Rodríguez-Teijeiro. Departament de Biologia Animal, Facultat de Biologia, Universitat de Barcelona, Avinguda Diagonal 645, E-08028 Barcelona, Spain.

M. Puigcerver. Departament de Didàctica de les Ciències Experimentals i la Matemàtica, Facultat de Formació del Professorat, Universitat de Barcelona, Passeig Vall d'Hebron 171, E-08035 Barcelona, Spain.

Corresponding author: F. Sardà-Palomera (e-mail: francesc.sarda@ctfc.cat).

*Present address: Grup d'Ecologia del Paisatge, Àrea de Biodiversitat, Centre Tecnològic Forestal de Catalunya, Carretera vella de Sant Llorenç de Morunys km 2, 25280 Solsona, Spain. 
(iv) sampling and selection of males by females (Bradbury 1981; Oring 1982; Höglund and Alatalo 1995).

In studies of leks, one unresolved problem is that a small number of males monopolize most matings. Consequently, many males that participate in leks fail to mate (Kokko 1997). Given that male aggregation and display is costly, it is not clear why unsuccessful males participate in leks. The queuing hypothesis proposes that there are direct, delayed benefits for these males (McDonald and Potts 1994; Kokko et al. 1998; Sæther 2002). For example, in the display of Long-tailed Manakin (Chiroxiphia linearis (Bonaparte, 1838)) male duos, only the alpha male is successful in approximately $85 \%$ of copulations. The beta male obtains future benefits only after queuing and ascending to alpha status, at which point he gains a territory and the benefits of female lek fidelity (McDonald and Potts 1994). Leks can also be explained by the "kin selection" theory (Kokko and Lindström 1996; Höglund et al. 1999; Petrie et al. 1999; Shorey et al. 2000; Krakauer 2005), which argues that individuals forming a lek have a certain degree of kinship. Thus, individuals that fail to mate also indirectly increase their fitness.

Several nonmutually exclusive hypotheses have been formulated to explain the function and evolution of leks (McDonald and Potts 1994; Höglund and Alatalo 1995; Kokko and Lindström 1996; Petrie et al. 1999; Sherman 1999; Gibson et al. 2002) from both male and female perspectives (see Höglund and Alatalo 1995 for more details). Two models take females as the driving force behind these aggregations. These are called the "female preference" model (Bradbury 1981) and the "hotshot" model (Beehler and Foster 1988). The female preference model assumes that females prefer male aggregations for various reasons, such as lower sampling effort, less predation risk, and the guarantee of selecting the topranking males. In contrast, the hotshot model proposes that females search for high-ranking males, while lower-ranking males gather around the "hotshot" males in an attempt to intercept females on their way to the top males (Beehler and Foster 1988). Alternatively, another model takes males as the driving force. This is called the "hotspot" model and proposes that males cluster in areas where female densities are higher, as a result of the overlapping of female home ranges (Bradbury et al. 1986). Finally, in the "black hole" model (Clutton-Brock et al. 1992; Stillman et al. 1993), females are harassed by males, forcing them to move around; by clustering, males are more likely to be encountered by females moving from one territory to another than if the males were not clustered.

Not all male aggregations can be described as leks (Höglund and Alatalo 1995). The Common Quail (Coturnix coturnix (L., 1758)) is a galliform species, an order that presents a high proportion of lekking species (Jiguet et al. 2000). The Common Quail is the only galliform that exhibits migratory behaviour (Guyomarc'h et al. 1998), and nomadic movements during the breeding season, in search of suitable but ephemeral habitats of mainly winter cereal crops (Rodríguez-Teijeiro et al. 2009), or in search of females in the case of males (Rodríguez-Teijeiro et al. 2006). In this species, males show aggregative patterns when they reach the breeding areas. Members of these male aggregations (of around 2-4 males) patrol their communal area (4-12 ha) without any territorial boundaries, and engage in intense call- ing competition (they are not in visual contact), the purpose of which is to attract both females and males (Guyomarc'h et al. 1998; Guyomarc'h 2003). Females arrive in the breeding areas asynchronously over a prolonged time period (several months, see Ghigi et al. 1935; Macchio et al. 1999), and male quail aggregations last throughout the breeding season.

These aggregative patterns resemble "exploded leks," which are described as loosely aggregated male displays that females attend for mating purposes (Emlen and Oring 1977; Höglund and Alatalo 1995). However, according to Höglund and Alatalo (1995), birds that have lek mating systems do not show parental care or pair-bonding. Male quails fulfil the first condition (Glütz Von Blotzheim et al. 1973), but they do show pair-bonding behaviour (Rodríguez-Teijeiro et al. 2003). When a female visits a group of males, an unknown process of selection and pair-bonding occurs. Mated pairs quickly move out of the prenuptial centre to settle $0.1-1 \mathrm{~km}$ away (Guyomarc'h et al. 1998), in contrast to what happens in leks. The mated pairs show stable pair-bonds until incubation begins. Pairs coordinate their behaviour and spend a great deal of time in close proximity, and both partners actively search for their mate when they are separated (Rodríguez-Teijeiro et al. 2003). The clear mate-guarding behaviour observed in males suggests a strategy to counteract the risk of being cuckolded (Danchin et al. 2008). Monitoring of radio-tagged quails has shown that females frequently switch mates. When an incomer is in better condition than the resident mate, switching occurs and the female establishes a bond with the new partner within the same breeding attempt (Rodríguez-Teijeiro et al. 1992; Rodrigo-Rueda et al. 1997; Rodríguez-Teijeiro et al. 2003).

The peculiar mating system of the Common Quail includes male aggregations similar to leks, but with some important differences: (i) pair-bonding; (ii) dynamic composition of male aggregations, which last throughout the breeding period; (iii) couples leaving the aggregation. As condition dependence is often important in sexually selected traits (Price et al. 1993; Andersson 1994; Rowe and Houle 1996), this provides an excellent opportunity to explore the function of the male aggregations in non-lek species, to consider why pair-bonds occur, and to analyse the role of male body condition in, as far as we know, this unique mating system.

Quails inhabit dense grassland and cereal crops, and are therefore very difficult to observe in the wild. Consequently, we designed a field experiment using walk-in funnel traps that contained either artificial male groups or single females, which served as sexual baits. We used these traps to study the formation of the male group, its maintenance during the breeding season, the interactions between the sexual baits and the free population, and to evaluate the role of body condition in free individual choices. Such tests are not very common in the literature (e.g., Höglund and Robertson 1990; Jiguet et al. 2000; Jiguet and Bretagnolle 2006), as the parameters that define a lek are difficult to establish. To sum up, this design allowed us to describe biological aspects associated with male aggregations in a species that does not fit the lek mating system, and to understand how this system could have evolved. 


\section{Materials and methods}

Field work was carried out in a $3 \mathrm{~km}^{2}$ area in Mas Esplugues $\left(41^{\circ} 25^{\prime} \mathrm{N}, 1^{\circ} 23^{\prime} \mathrm{E}, 628 \mathrm{~m}\right.$ above sea level), in the province of Tarragona (northeast Spain). The study area is a short valley where winter cereals (barley and wheat) are grown from the beginning of May to mid-July, when they are harvested. Thus, this area provides a suitable habitat for the Common Quail (Cramp and Simmons 1980).

\section{Field experiment design}

During the breeding seasons (from May to early August) of 2000 to 2004, we placed 15 walk-in funnel traps $(144 \mathrm{~cm} \times 67 \mathrm{~cm} \times 87 \mathrm{~cm})$ containing either adult male or female quails (in individual compartments), on cereal field margins in the study area. The quails in the traps acted as "sexual bait" or decoys, attracting individuals with their calls (Berthet 1946; Moreau 1951; Rodríguez-Teijeiro et al. 2003).

Food (vitamin-supplemented grains - wheat, 3:1 w/w) and water were supplied ad libitum both to the bait and to captured birds.

Traps were checked every 2-3 days. The individuals used as decoys were changed from year to year. These decoy quails were males and females captured in the study area with the aid of nets in previous years. Subsequently, they were maintained and raised on a lucerne crop delimited by wire mesh and covered with netting.

Ten funnel traps containing males were placed on several field margins, in three-male groups of 2 traps $15 \mathrm{~m}$ apart. One funnel trap contained one male (hereinafter a one-male trap) and a second one contained two males as bait in different compartments (hereinafter a two-male trap), thus imitating a male aggregation within the variation range (2-4 males) observed in natural conditions for this species. Moreover, five individual traps that each contained one female as bait were also set up (hereinafter a female trap), thereby simulating individual females (Fig. 1).

All the traps were set up to protect birds against predators, and a mammal repellent was renewed at each visit to avoid predation.

In analyses related to body condition and trap selection with regard to the number of male baits or its sex composition, only cases in which single individuals were trapped were taken into account, as it would be impossible to determine which cues led a bird into a trap if other nonbait quails were also found there. Moreover, when an individual entered the same trap more than once, only the first time was taken into consideration. The rest of the entries into the trap were excluded from the analyses, to avoid the effect of experience on individuals' choices. Trapped quails were held inside the cages for a maximum of 2 days.

A weekly male census in the area (see Rodríguez-Teijeiro et al. 1992), taken during both the experiment and subsequent monitoring of mowing, revealed that depending on the year, $75 \%-95 \%$ of the individuals that visited the study area were trapped using this method. The following measurements were taken for all captured quails: body mass, to the nearest $1 \mathrm{~g}$, with a Pesola balance; and flattened wing length, to the nearest $1 \mathrm{~mm}$, with a ruler and stop.

The sexual development of the captured quails was assessed by measuring the length of the cloacal vent (Guyo- marc'h et al. 2001). In all cases, individuals had an inflated cloacal vent and were sexually mature, as was also indicated by the presence of proctodeal foam (Seiwert and Adkins-Regan 1998). Finally, we measured the width of the pectoral lipid band, which is a good indicator of the migratory impulse. None of the individuals had a lipid band of more than $11 \mathrm{~mm}$ in width, and consequently, they were classified as having no fat reserves (score 0) according to the criteria of Saint-Jalme (1990) and Guyomarc'h and Belhamra (1998). In other words, none of our captured individuals were still fat (fatness would indicate that they could be on a migratory route to northern Europe).

\section{Radio tracking}

In the 2004 and 2005 breeding seasons, we attached backpack radio transmitters (TW4 Biotrack models) to individuals captured in funnel traps before they were released. Every 2 days, these individuals were monitored with a telemetry receiver (R1000 Communication Specialist INC 148-174 Mhz) and a three-element Yagi antenna to establish their mating status. When a radio-tagged quail was detected alone, it was scared into flight to check whether it was paired with an unmarked bird (see further details in Rodrigo-Rueda et al. 1997; Rodríguez-Teijeiro et al. 2003). Paired males were referred to as consort males. In some cases, the instant a couple was separated, a second and previously undetected male started to call close to the area where the radio-tagged couple had been flushed, apparently in an attempt to attract the attention of the female. These males were referred to as satellite males.

The protocol was approved by the ethics committee of the University of Barcelona (UB) and the study complies with current Spanish laws. All institutional guidelines for animal care and use were followed.

\section{Data analysis}

Normality and homogeneity of variance were tested with the Lilliefors test and Levene's test, respectively, in all the parametric analyses.

Chi square and goodness of fit $\chi^{2}$ square were applied to check male and female preferences for each kind of trap (one-male traps, two-male traps, and female traps); as degrees of freedom of these analyses $=1$, Yates corrected $\chi^{2}$ was applied, in accordance with Zar (1984). The body mass and the flattened wing length measurements were used, applying the criterion suggested by Lormée et al. (2003) for calculating a body condition index, which was defined by Jakob et al. (1996) as the residuals of an ordinary least squares linear regression of mass against wing length. The limitations of this method, discussed by Green (2001), have been refuted by Ardia (2005) and by Schulte-Hostedde et al. (2005). The body condition index was estimated from a "standard" population consisting of both adult and yearling males (yearlings were quails that still had not developed an "anchor" pattern on their throat feathers (see Cramp and Simmons 1980; Puigcerver 1990)), captured between 2000-2004 in three areas in Catalonia (Figuerola del Camp, Alp, and the study area). An ANCOVA between mass and wing length revealed that yearlings and adults did not significantly differ in slope $\left(F_{[1,625]}=\right.$ $3.46, P=0.07)$. However, they had significantly different intercepts, which were lower in yearlings $\left(F_{[1,625]}=18.39, P<\right.$ 
Fig. 1. Aerial image of cereal fields in the study area with the location of the funnel traps marked in winter cereal fields (in yellow, web version only). Circles show simulated aggregations of three male Common Quails (Coturnix coturnix); triangles, one-male traps; squares, twomale traps; isolated rectangles, female traps.

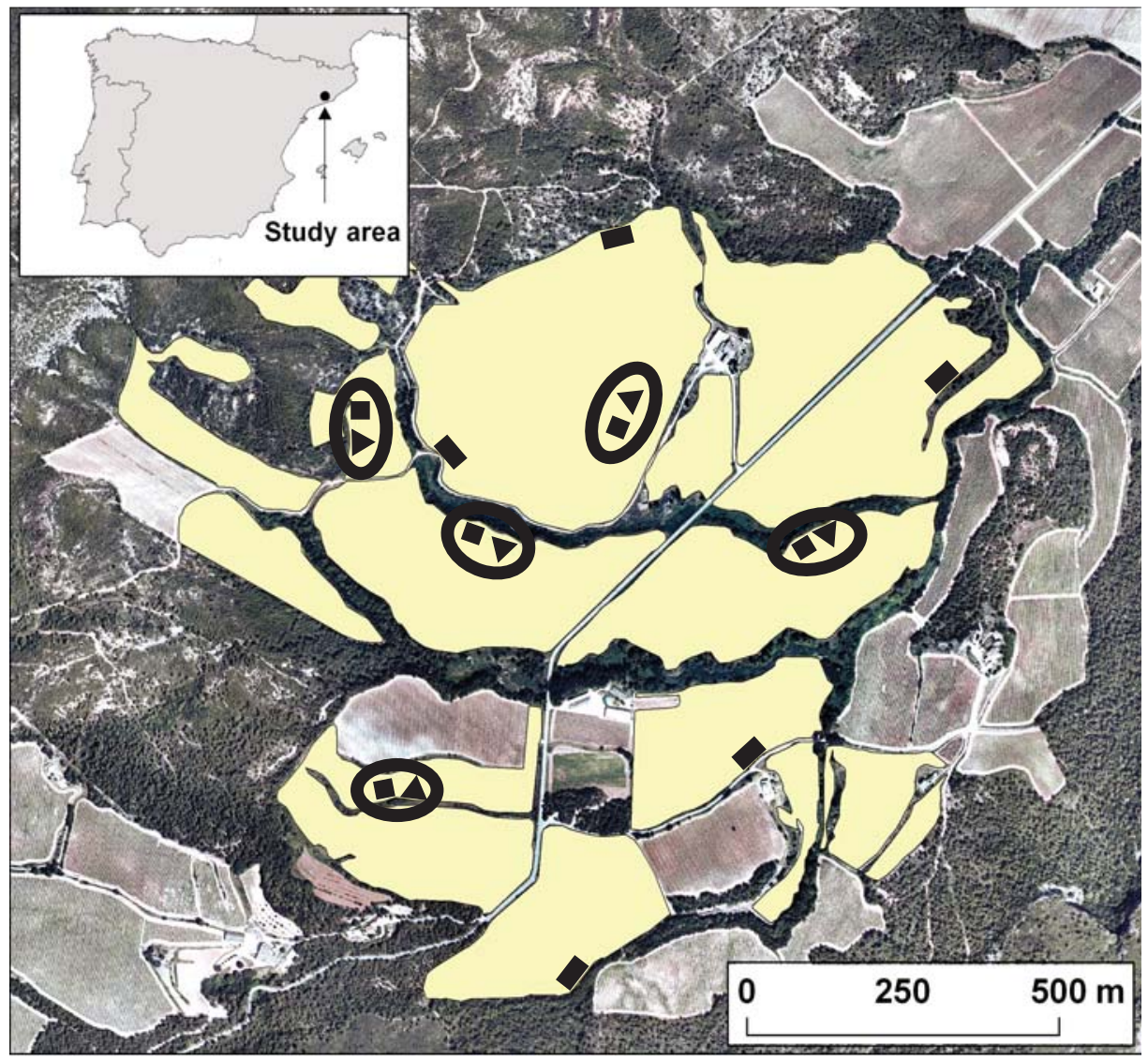

0.01). Consequently, we calculated two regression lines of wing length - mass: one for adults and another for yearlings. The linear regression for adults was as follows: mass = $11.1+0.73 \times$ wing length, $r^{2}=0.10, P<0.01, n=462$. For yearlings it was mass $=0.11+0.80 \times$ wing length, $n=$ $167, r^{2}=0.10, P<0.01$.

Interannual differences in the body condition of individuals were observed and correlated negatively with the population density, which was defined as the number of males ringed each year per square kilometre (Spearman's rank correlation: $\left.r_{\mathrm{S}}=-0.90, P=0.04, n=5\right)$. As these interannual changes in population density could potentially affect the trap choice of free individuals (males or females), we carried out a twoway ANOVA, in which we considered the variables "year" and "trap choice" as factors and "body condition" as the dependent variable.

With regard to the possibility of a change in mass owing to the conditions during captivity in wild birds that were measured 1 to 2 days after capture in the funnel traps, we compared the mass of adult individuals captured with traps with a sample of 89 adult individuals that were caught with nets and decoys and measured immediately after capture in the same study area and years. No significant differences were found $\left(t_{[174]}=1.73, P=0.09\right.$, nets $($ mean $\pm \mathrm{SD})=-0.13 \pm$ 5.29 , traps $($ mean $\pm \mathrm{SD})=-1.73 \pm 6.35)$. This indicates that no significant changes occurred in the mass of individuals as a result of the conditions during captivity.

\section{Results}

\section{Captures}

A total of 161 individuals (31 females and 130 males, of which 43 were yearlings) were captured in the traps during the 5 years of study (2000-2004). Table 1 shows the distribution of these captures by year. In $88 \%$ of cases, only one male was trapped at a time. In the remaining $12 \%$ of cases, we trapped two (10.6\%) and even three males $(1.4 \%)$. A lower percentage of females were trapped alone $(77.4 \%)$. In the remaining cases, a female was trapped with a wild male $(12.9 \%)$ or with another female $(9.7 \%)$.

\section{Trap preferences of wild individuals by sex}

The number of birds of each category (adult males, yearling males, and females) found in each male-baited trap was not uniformly distributed; they were mainly attracted by twomale traps rather than by one-male traps (Yates' $\chi^{2}$ goodness-of-fit test, adult males: $\chi_{[1]}^{2}=13.79, P<0.01$; yearling males: $\chi_{[1]}^{2}=13.88, p<0.01$; females: $\chi_{[1]}^{2}=$ 15.61, $P<0.01$, see Fig. 2).

In contrast, yearlings and adult males showed distinctly different preferences as regards the sex of the bait (Yates' $\chi^{2}$ test: $\chi_{[1]}^{2}=6.90, P<0.01$, Fig. 3). Adult males were more frequently caught in traps with females as bait (female traps, $65 \%)$ than in those holding males as decoys (35\%, Yates' $\chi^{2}$ goodness-of-fit test: $\left.\chi_{[1]}^{2}=7.77, P<0.01\right)$, whereas yearlings 
Table 1. Number of individuals of Common Quail (Coturnix coturnix) entering the traps during the study period.

\begin{tabular}{cccc}
\hline Year & Adult males & Yearling males & Females \\
\hline 2000 & 10 & 8 & 2 \\
2001 & 8 & 8 & 4 \\
2002 & 31 & 8 & 9 \\
2003 & 17 & 9 & 4 \\
2004 & 21 & 10 & 12 \\
\hline
\end{tabular}

did not show any preferences for male (58\%) or female (42\%) decoys in the traps (Yates' $\chi^{2}$ goodness-of-fit test: $\chi_{[1]}^{2}=$ $1.49, P=0.22$; see Fig. 3). Females were only trapped using males as bait (male traps, 100\%).

\section{Body condition of wild individuals}

At a population level, the body condition of captured wild adult males did not undergo significant statistical changes $(F$ ${ }_{[6,85]}=1.23, P=0.30$ ) during the breeding season (principally May-June), when we analysed our data by time intervals of 2 weeks. Yearling male body condition also remained stable during the breeding season $\left(F_{[4,38]}=0.41\right.$, $P=0.80$ ). Therefore, the body condition index is not influenced by the physiological status of the bird, and does not exhibit significant changes during the breeding season when comparing the beginning with the end of the breeding season.

However, significant differences in the body condition index (two-way ANOVA) were found in wild adult males with regard to the sex of quails acting as bait (choice factor: $F$ ${ }_{[1,77]}=4.78, P=0.03$ ), and year (year factor: $F_{[4,77]}=2.71$, $P=0.04)$. These differences in the body condition are consistent over the years, since although significant differences in the body condition of wild adult males occurred between years, this did not affect their choice (year $\times$ choice interaction: $F_{[4,77]}=0.29, P=0.88$, Fig. $4 a$ ).

Thus, adult males caught in male traps had a better body condition index (mean $\pm \mathrm{SD}=0.5 \pm 5.2, n=30$ ) than those caught in female traps (mean $\pm \mathrm{SD}=-2.9 \pm 6.6, n=57$ ), regardless of interannual changes in their body condition due to interannual differences in the density of population.

However, no differences in body condition index (two-way ANOVA) were found in yearling males, either in terms of trap choice (choice factor: $F_{[1,33]}=1.32, P=0.28$ ) or year (year factor: $F_{[4,33]}=0.02, P=0.87$; interaction, year $\times$ choice: $F_{[4,33]}=1.13, P=0.35$, Fig. $\left.4 b\right)$. This suggests that adults and yearlings have different reproductive strategies.

\section{Radio-tracking data}

Sixty-four individuals (37 males and 27 females) were radio-tagged during the 2004 and 2005 breeding seasons. In $37.4 \%$ of the radio-tagged couples observed, a satellite male was detected close to them. These satellite males generally remained silent, only calling when pairs were separated, possibly in an attempt to attract the female by calling while the consort male searched for the female.

Satellite males that had previously been captured in traps entered female traps in a significantly higher proportion than consort males that had been captured in traps (Mann-Whitney $U$ test, $\left.U=0, P=0.01, n_{1}=5, n_{2}=4\right)$.
Fig. 2. Number of wild individuals of Common Quail (Coturnix coturnix) entering one-male traps and two-male traps. (a) Wild adult males $\left(\chi_{[1]}^{2}=13.79, P<0.01\right),(b)$ wild yearling males $\left(\chi_{[1]}^{2}=\right.$ $13.88, p<0.01)$, and $(c)$ wild females $\left(\chi_{[1]}^{2}=15.61, P<0.01\right)$. Solid columns, number of individuals observed, shaded columns, number of individuals expected to enter the traps assuming a uniform distribution.
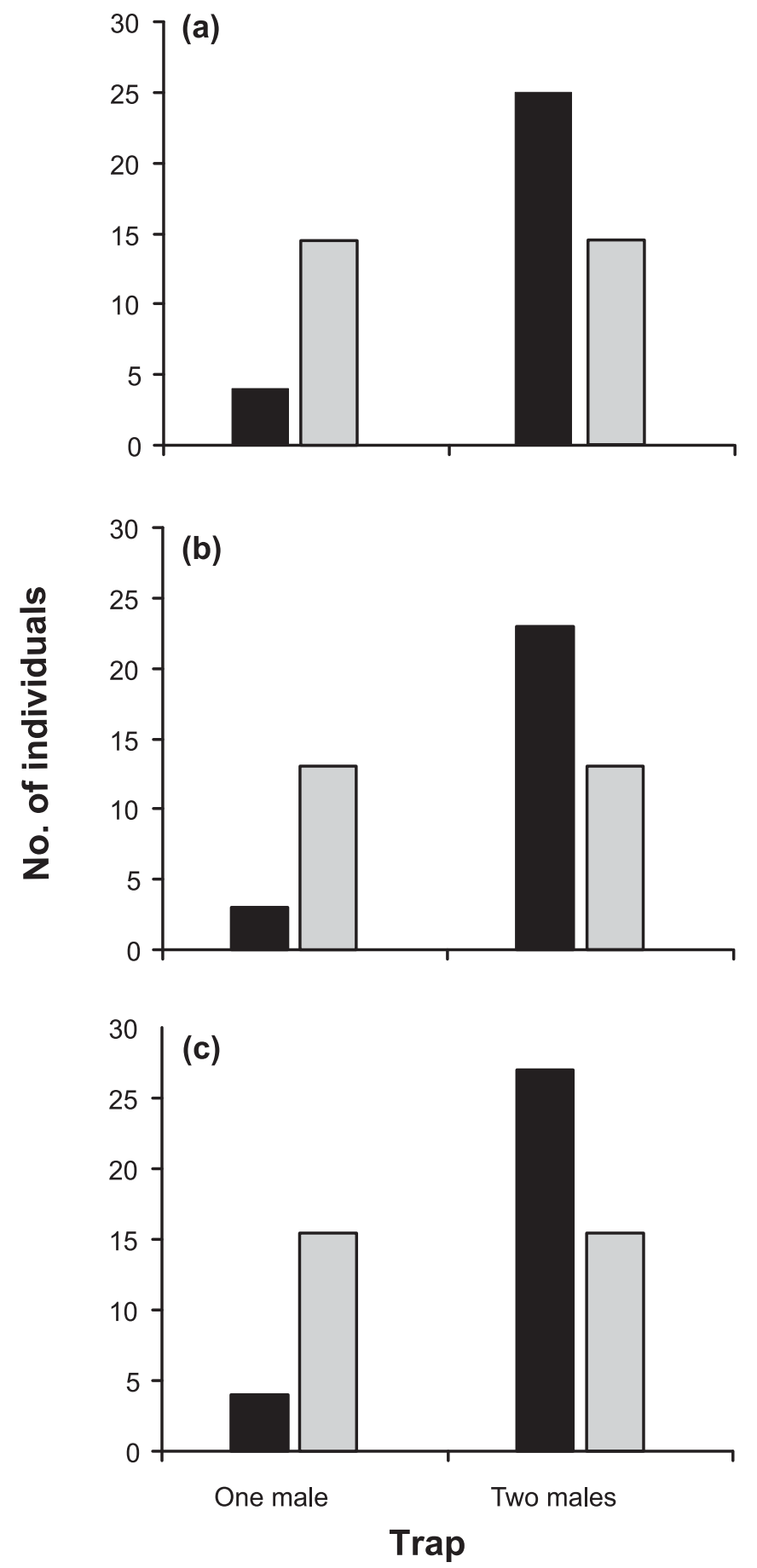

\section{Discussion}

Results showed that during the breeding season, quails are mainly trapped using two males as bait, rather than in traps with only one male, independently of sex and age. With re- 
Fig. 3. Number of wild adult males (solid columns) and wild yearlings (open columns) of Common Quail (Coturnix coturnix) entering traps with a male or a female as bait. Adult males showed higher preference for female baits than yearlings (Yates' $\chi^{2}$ test: $\chi_{[1]}^{2}=$ 6.90, $P<0.01)$.

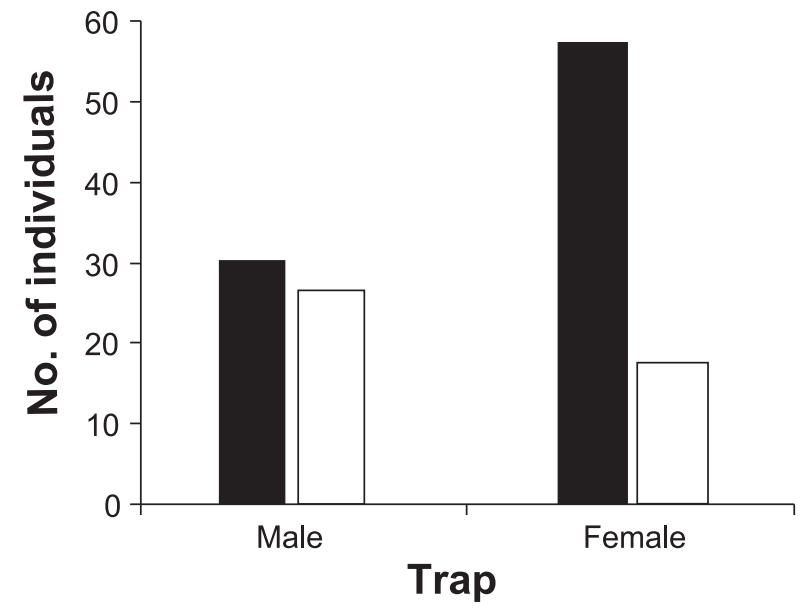

gard to the sex of free individuals, females were only trapped in male traps, while adult males were mostly trapped in female traps. However, males captured in male traps had better body condition than individuals captured in female traps. These results show that male aggregations are composed of those males with better body condition (hereinafter highranking males), and that females prefer to join these groups rather than single males. This strongly suggests that wild females prefer to join grouped males, where they can find high-ranking males. The probability of these males attracting a female is higher when they are in a group than when they are alone.

Male calls reflect the body condition of quail males and, therefore, the male's quality (Puigcerver et al. 1999). However, although call coordination of dispersed groups of males has been described (Guyomarc'h et al. 1998; Guyomarc'h 2003), our observation that traps containing males as bait captured other males shows that there are closer interactions between males, and that the "exploded lek" classification for the Common Quail mating system is not clear. Probably, male rank is not decided by call interactions alone. Physical interactions between males (Rodrigo-Rueda et al. 1997) also contribute to establishing the male hierarchy and, therefore, to mating success.

During the breeding season, most males do not remain in the same area for more than 2 weeks (Rodríguez-Teijeiro et al. 1992). Our results strongly suggest that male mating behaviour varies according to body condition, which may be crucial in male-male interactions. Apparently, males with poorer body condition (hereinafter low-ranking males) do not benefit from proximity to male groups. The number of males in a group remained constant over the years (2-3 males, mean: 2.91). An increase in population density caused an increase in the number of groups, but not in their size (Rodríguez-Teijeiro et al. 1999). However, the main difference between this mating system and a true lek system is that pair-bonding occurs when a female visits a group. As a result, a male leaves the group and a vacancy arises. As the result of a very high turnover rate of males throughout the
Fig. 4. (a) Captured adult males, and (b) captured yearling males of Common Quail (Coturnix coturnix). Solis circles represent the mean body condition of wild males captured in male traps; open circles represent the mean body condition of wild males captured in female traps. Error bars represent the 0.95 confidence intervals.

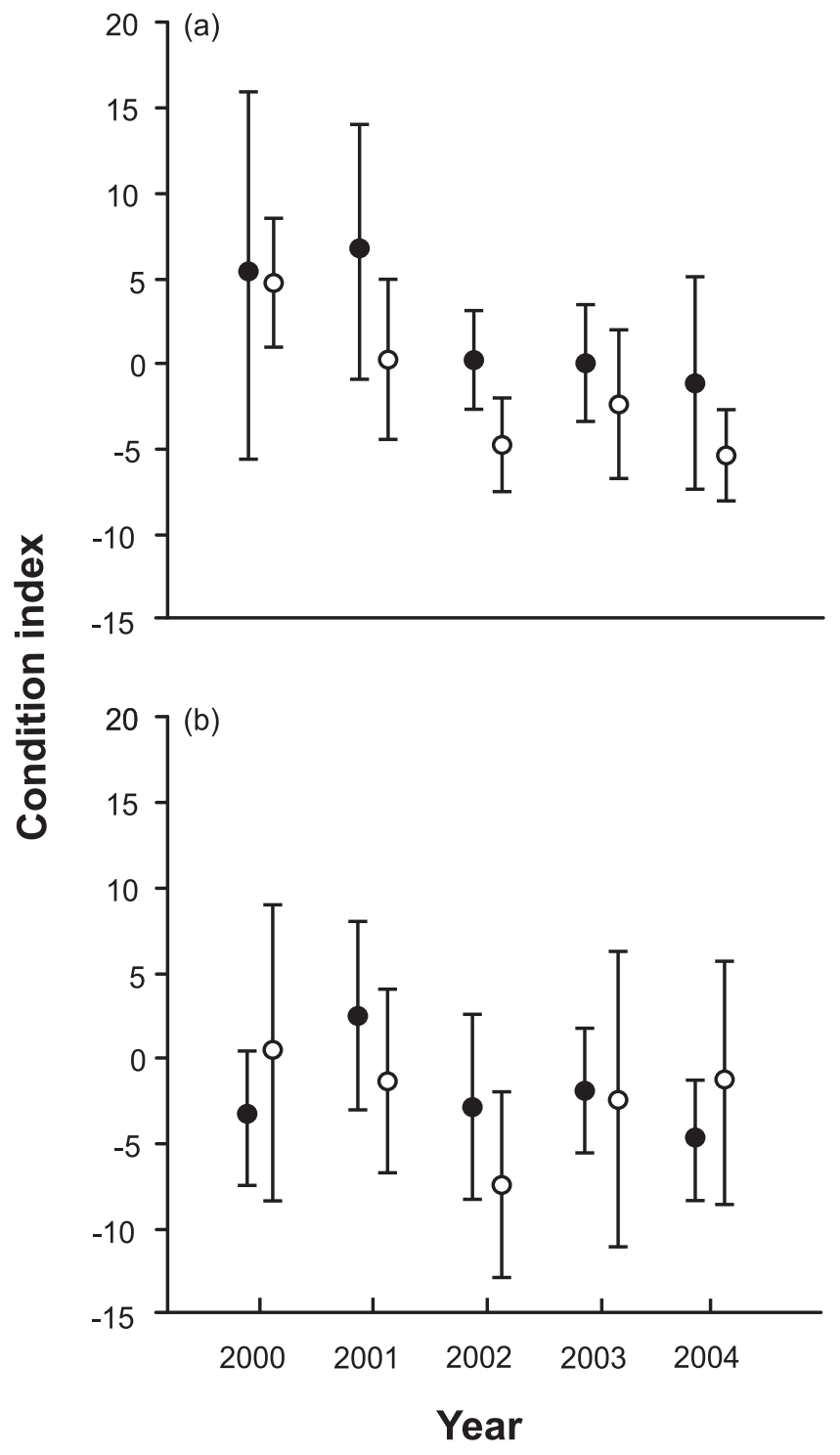

entire breeding season (95\% in less than 15 days, see Rodríguez-Teijeiro et al. 1992), together with the ability of males to re-mate fairly quickly (Rodrigo-Rueda et al. 1997; Rodríguez-Teijeiro et al. 2003), the composition of individuals forming these aggregations is not stable over time; this situation would facilitate other males joining the group, thus enabling a queuing process. Therefore, the low mean life span of the Common Quail (Puigcerver et al. 1992) does not hinder the development of social queuing in this species. This strategy has traditionally been related to animals with a long life expectancy (Kokko and Johnstone 1999). However, our results suggest that it might also be viable in species with a short life span.

Females play a key role in this mating system. Owing to habitat characteristics, visual contact between individuals is only possible at a very short distance. Therefore, vocal calls 
provide a means of interaction between individuals. While males use intense calls during the breeding season, females do not reveal their position in the field as frequently as males do; they only sing when the consort male is accidentally separated or when they cannot reach the singing male, i.e., when they are inside cages (F. Sardà-Palomera, M. Puigcerver, and J.D. Rodríguez-Teijeiro, personal observation). In both cases, females call for very short periods (a few seconds) at very low intensity (Guyomarc'h et al. 1998). Thus, the female call implies that the females can decide when and where they want to be detected, thereby avoiding male harassment.

In our experiment, the low-ranking males showed greater attraction to female traps (single females) than the high-ranking males. This finding, together with the presence of satellite males, may indicate a different mating strategy in lowranking males, in which they attempt to have sporadic extrapair copulation. This satellite strategy also explains the existence of pair-bonds: owing to the presence of satellite males monitoring the mating success of others by clustering around successful pair-bonds and attempting to benefit from their success by seeking extra-pair fertilizations, the fertilization of female eggs by the consort male is not guaranteed. Consequently, consort males are obliged to guard their female partners almost constantly throughout the fertile period in an attempt to minimize the risk of extra-pair copulations (Birkhead and Møller 1995).

In general, yearling males had a lower body condition index than adult males, and were also caught in traps with male and female decoys. However, no significant differences were found in their preference of bait sex. This could be explained by the fact that there is a high variability in the sexual activity of yearlings: some of them are 3-months-old (or even less), and they are probably not sexually active, whereas other yearlings are up to 6-months-old and are able to reproduce. This variability would result in some yearlings interacting socially with the reproductive population, whilst others interact sexually.

To sum up, the Common Quail has evolved a mating system that may be induced by the biotope, which impedes visual contact between individuals, and by its migratory and nomadic movements, which form the basis of dynamic male aggregations throughout the breeding season. Our results suggest that adult male mating behaviour varies according to relative body condition, which may be crucial in male-male interactions. In this context, male quails with better body condition tend to search for other males, forming a group, to mate with a female. In contrast, males with poorer body condition would wait around groups or couples for their chance to mate in a satellite male strategy. Within this scenario, a male could mate several times and may have many descendants in a relatively short period of time, even though this species has a very short life expectancy.

Having reached these conclusions, some new questions arise: is this mating system an intermediate step between classical sequential polygamy and leks, or should it be considered a deviation derived from lekking systems? Unfortunately, the phylogenetic position of the Common Quail with respect to other galliforms is not clear (Dimcheff et al. 2002; Kimball and Braun 2008), and a phylogenetic study from the point of view of mating systems should be the next step to clarify the evolution of such interesting strategies. In spite of this, our findings clearly support male aggregations in which male body condition is a key factor.

\section{Acknowledgements}

We thank J. Höglund, D.W. Mock, and two anonymous reviewers who read the first draft and provided useful comments and suggestions. We thank all the students and collaborators who helped with the field work. We also thank the Dirección General de Investigación Científica y Técnica (BOS2000-0564-C02-01 and CGL2004-05308/BOS projects), the Direcció General de Recerca (2005-SGR-00090), and the Àrea d'Activitats Cinegètiques of the Generalitat (Government of Catalonia) for financial support. The English version of the manuscript has been revised by Robin Rycroft from the University of Barcelona's Linguistic Advice Service.

\section{References}

Andersson, M. 1994. Sexual selection. Princeton University Press. Princeton, N.J.

Ardia, D.R. 2005. Super size me: an experimental test of the factors affecting lipid content and the ability of residual body mass to predict lipid stores in nestling European Starlings. Funct. Ecol. 19 (3): 414-420. doi:10.1111/j.1365-2435.2005.00997.x.

Arnold, S.J., and Duvall, D. 1994. Animal mating systems - a synthesis based on selection theory. Am. Nat. 143(2): 317-348. doi:10.1086/285606.

Beehler, B.M., and Foster, M.S. 1988. Hotshots, hotspots, and female preference in the organization of lek mating system. Am. Nat. 131 (2): 203-219. doi:10.1086/284786.

Berthet, G. 1946. Le chant de la femelle de la caille Coturnix coturnix. Alauda, 14: 161-162.

Birkhead, T.M., and Møller, A.P. 1995. Extra-pair copulation and extra-pair paternity in birds. Anim. Behav. 49(3): 843-848. doi:10. 1016/0003-3472(95)80217-7.

Bradbury, J.W. 1981. The evolution of leks. In Natural selection and social behavior. Edited by R.D. Alexander and D.W. Tinkle. Chiron Press, New York, and Blackwell Scientific Publications, Oxford. pp. 138-169.

Bradbury, J.W., Gibson, R., and Tsai, I.M. 1986. Hotspots and the dispersion of leks. Anim. Behav. 34(6): 1694-1709. doi:10.1016/ S0003-3472(86)80257-3.

Clutton-Brock, T.H., Price, O.F., and MacColl, A.D.C. 1992. Mate retention, harassment, and the evolution of ungulate leks. Behav. Ecol. 3(3): 234-242. doi:10.1093/beheco/3.3.234.

Cramp, S., and Simmons, K.E. (Editors). 1980. Quail. In Handbook of the birds of Europe, the Middle East and North Africa. The birds of the western palaearctic. Oxford University Press, Oxford. pp. 496-503.

Danchin, E., Giraldeau, L.-A., and Cézilly, F. 2008. Behavioural ecology. Oxford University Press, Oxford.

Davies, N.B. 1991. Mating systems. In Behavioural ecology. An evolutionary approach. Edited by J.R. Krebs and N.B. Davies. Blackwell Scientific Press, Oxford. pp. 263-294.

Dimcheff, D.E., Drovetski, S.V., and Mindell, D.P. 2002. Phylogeny of Tetraoninae and other galliform birds using mitochondrial $12 \mathrm{~S}$ and ND2 genes. Mol. Phylogenet. Evol. 24(2): 203-215. doi:10. 1016/S1055-7903(02)00230-0. PMID:12144757.

Emlen, S.T., and Oring, L.W. 1977. Ecology, sexual selection and the evolution of mating systems. Science (Washington, D.C.), 197 (4300): 215-223. doi:10.1126/science.327542. PMID:327542.

Ghigi, F., Agostini, A., and Rotondi, M. 1935. Studio sulla 
migrazione della Quaglia (Coturnix c. coturnix) compiuti dalla Stazione Ornitologica di Castelfusano. Ric. Zool. Appl. Caccia, 9: 33-99.

Gibson, R.M., Aspbury, A.S., and McDaniel, L.L. 2002. Active formation of mixed-species grouse leks: a role for predation in lek evolution? Proc. R. Soc. Lond. B Biol. Sci. 269(1509): 25032507. doi:10.1098/rspb.2002.2187. PMID:12573063.

Glütz Von Blotzheim, U.N., Bauer, K.M., and Bezzel, E. 1973. Handbuch der Vögel Mitteleuropas. Akademische Verlagsgesellschaft, Frankfurt am main, Germany.

Gowaty, P.A. 1985. Multiple parentage and apparent monogamy in birds. In Avian monogamy. Edited by P.A. Gowaty and D.W. Mock. The American Ornithologist Union, Washington, D.C. pp. 11-17.

Green, A.J. 2001. Mass/length residuals: measures of body condition or generators of spurious results? Ecology, 82(5): 1473-1483. doi:10.1890/0012-9658(2001)082[1473:MLRMOB]2.0.CO;2.

Guyomarc'h, J.C. 2003. Elements for a common quail (Coturnix c. coturnix) management plan. Game Wildl. Sci., 20: 1-92.

Guyomarc'h, J.C., and Belhamra, M. 1998. Les effets de la sélection sur l'expression des tendances sexuelles et migratoires chez la caille des blés (Coturnix c. coturnix). Cah. Ethol., 18: 1-16.

Guyomarc'h, J.C., Combreau, O., Puigcerver, M., Fontoura, P.A., and Aebischer, N.J. 1998. Quail. In Birds of the weastern palaearctic. Update 2. Edited by E. Olgivie. Oxford University Press, Oxford. pp. 27-46.

Guyomarc'h, C., Lumineau, S., Vivien-Roels, B., Richard, J., and Deregnaucourt, S. 2001. Effect of melatonin supplementation on the sexual development in European quail (Coturnix coturnix). Behav. Processes, 53(1-2): 121-130. doi:10.1016/S0376-6357(01) 00133-4. PMID:11254999.

Höglund, J., and Alatalo, R.V. 1995. Leks. Princetown University Press, Princeton, N.J.

Höglund, J., and Robertson, J.G.M. 1990. Female preferences, male decision rules and the evolution of leks in the great snipe Gallinago media. Anim. Behav. 40(1): 15-22. doi:10.1016/S00033472(05)80661-X.

Höglund, J., Alatalo, R.V., Lundberg, A., Rintamäki, P.T., and Lindell, J. 1999. Microsatellite markers reveal the potential for kin selection on black grouse leks. Proc. R. Soc. Lond. B Biol. Sci. 266(1421): 813-816. doi:10.1098/rspb.1999.0710.

Jakob, E.M., Marshall, S.D., and Uetz, G.W. 1996. Estimating fitness: a comparison of body condition indices. Oikos, 77(1): 61-67. doi: $10.2307 / 3545585$.

Jiguet, F., and Bretagnolle, V. 2006. Manipulating lek size and composition using decoys: an experimental investigation of lek evolution models. Am. Nat. 168(6): 758-768. doi:10.1086/ 508808. PMID:17109318.

Jiguet, F., Arroyo, B., and Bretagnolle, V., V. 2000. Lek mating systems: a case study in the Little Bustard Tetrax tetrax. Behav. Processes, 51(1-3): 63-82. doi:10.1016/S0376-6357(00)00119-4. PMID:11074312.

Kimball, R.T., and Braun, E.L. 2008. A multigene phylogeny of Galliformes supports a single origin of erectile ability in nonfeathered facial traits. J. Avian Biol. 39: 438-445.

Kokko, H. 1997. The lekking game: can female choice explain aggregated male displays? J. Theor. Biol. 187(1): 57-64. doi:10. 1006/jtbi.1997.0414.

Kokko, H., and Johnstone, A. 1999. Social queuing in animal societies: a dynamic model of reproductive skew. Proc. R. Soc. Lond. B Biol. Sci. 266(1419): 571-578. doi:10.1098/rspb.1999. 0674.

Kokko, H., and Lindström, J. 1996. Kin selection and the evolution of leks: whose success do young males maximize? Proc. R. Soc.
Lond. B Biol. Sci. 263(1372): 919-923. doi:10.1098/rspb.1996. 0136 .

Kokko, H., Lindström, A., Alatalo, R.V., and Rintamäki, P.T. 1998. Queuing for territory positions in the lekking black grouse (Tetrao tetrix). Behav. Ecol. 9(4): 376-383. doi:10.1093/beheco/9.4.376.

Krakauer, A.H. 2005. Kin selection and cooperative courtship in wild turkeys. Nature (London), 434(7029): 69-72. doi:10.1038/ nature03325. PMID:15744300.

Ligon, J.D. 1999. The evolution of avian breeding systems. Oxford University Press, Oxford.

Lormée, H., Jouventin, P., Trouve, C., and Chastel, O. 2003. Sexspecific patterns in baseline corticosterone and body condition changes in breeding Red-footed Boobies Sula sula. Ibis, 145(2): 212-219. doi:10.1046/j.1474-919X.2003.00106.x.

Macchio, S., Messineo, A., Licheri, D., and Spina, F. 1999. Atlante della distribuzione geografica e stagionale degli uccelli inanellati in Italia negli anni 1980-1994. Biol. Conserv. Fauna, 103: 1-276.

McDonald, D.B., and Potts, W.K. 1994. Cooperative display and relatedness among males in a lek-mating bird. Science (Washington, D.C.), 266(5187): 1030-1032. doi:10.1126/science.7973654. PMID:7973654.

Moreau, R.E. 1951. The British statuts of the quail and some problems of its biology. Br. Birds, 44: 257-276.

Oring, L.W. 1982, Avian mating systems. In Avian biology. Edited by D.S. Farner, J.R. King, and K.C. Parkes. Academic Press, New York. pp. 1-92.

Petrie, M., Krupa, A., and Burke, T. 1999. Peacocks lek with relatives even in the absence of social and environmental cues. Nature (London), 401(6749): 155-157. doi:10.1038/43651.

Price, T., Schluter, N.D., and Heckman, E. 1993. Sexual selection when the female directly benefits. Biol. J. Linn. Soc. 48(3): 187211. doi:10.1111/j.1095-8312.1993.tb00887.x.

Puigcerver, M. 1990. Contribución al conocimiento de la biología y ecoetología de la codorniz (Coturnix c. coturnix). Universitat de Barcelona, Barcelona, Spain.

Puigcerver, M., Gallego, S., Rodríguez, J.D., and Senar, J.C. 1992. Survival and mean life span of the quail Coturnix c. coturnix. Bird Study, 39(2): 120-123. doi:10.1080/00063659209477108.

Puigcerver, M., Rodríguez-Teijeiro, J.D., Zijlstra, W., Bonet, V., and Gallego, S. 1999. Indicators of male quality in the call of the common quail Coturnix coturnix. Hungarian Small Game Bulletin (Magyar Apróvad Közlemények), 5: 119-128.

Rodrigo-Rueda, F.J., Rodríguez-Teijeiro, J.D., Puigcerver, M., and Gallego, S. 1997. Mate switching in a non-monogamous species? The case of the common quail (Coturnix coturnix). Ethology, 103 (5): 355-364. doi:10.1111/j.1439-0310.1997.tb00151.x.

Rodríguez-Teijeiro, J.D., Puigcerver, M., and Gallego, S. 1992. Mating strategy in the European quail (Coturnix c. coturnix) revealed by male population density and sex-ratio in Catalonia (Spain). Gibier Faune Sauvage, 9: 377-386.

Rodríguez-Teijeiro, J.D., Cordero, P.J., Puigcerver, M., Gallego, S., and Parkin, D.T. 1999. Genetic similarities between males of common quail: a DNA fingerprinting analysis. Ethology, 105 (Suppl. 34): 215.

Rodríguez-Teijeiro, J.D., Puigcerver, M., Gallego, S., Cordero, P., and Parkin, D.T. 2003. Pair bonding and multiple paternity in the polygamous common quail (Coturnix coturnix). Ethology, 109(4): 291-302. doi:10.1046/j.1439-0310.2003.00873.x.

Rodríguez-Teijeiro, J.D., Barroso, A., Gallego, S., Puigcerver, M., and Vinyoles, D. 2006. Orientation-cage experiments with the European Quail during the breeding season and autumn migration. Can. J. Zool. 84(6): 887-894. doi:10.1139/Z06-070.

Rodríguez-Teijeiro, J.D., Sardà-Palomera, F., Nadal, J., Ferrer, X., Ponz, C., and Puigcerver, M. 2009. The effects of mowing and 
agricultural landscape management on population movements of the common quail. J. Biogeogr. 36(10): 1891-1898. doi:10.1111/j. 1365-2699.2009.02109.x.

Rowe, L., and Houle, D. 1996. The lek paradox and the capture of genetic variance by condition dependent traits. Proc. R. Soc. Lond. B Biol. Sci. 263(1375): 1415-1421. doi:10.1098/rspb.1996.0207.

Sæther, S.A. 2002. Female calls in lek-mating birds: indirect mate choice, female competition for mates, or direct mate choice? Behav. Ecol. 13(3): 344-352. doi:10.1093/beheco/13.3.344.

Saint-Jalme, M. 1990. La reproduction chez la Caille des blés (Coturnix c. coturnix). Études expérimentales des cycles saisonniers et de la variabilité interindividuelle. University of Rennes, Rennes, France.

Schulte-Hostedde, A.I., Zinner, B., Millar, J.S., and Hickling, G.J. 2005. Restitution of mass-size residuals: validation body condition indices. Ecology, 86(1): 155-163. doi:10.1890/04-0232.
Seiwert, C.M., and Adkins-Regan, E. 1998. The foam production system of the male japanese quail: characterization of structure and function. Brain Behav. Evol. 52(2): 61-80. doi:10.1159/ 000006553. PMID:9681161.

Sherman, P.W. 1999. Birds of a feather lek together. Nature (London), 401(6749): 119-120. doi:10.1038/43574.

Shorey, L., Piertney, S., Stone, J., and Höglund, J. 2000. Fine-scale genetic structuring on Manacus manacus leks. Nature (London), 408(6810): 352-353. doi:10.1038/35042562. PMID:11099040.

Stillman, R.A., Clutton-Brock, T.H., and Sutherland, W.J. 1993. Black holes, mate retention, and the evolution of ungulate leks. Behav. Ecol. 4(1): 1-6. doi:10.1093/beheco/4.1.1.

Zar, J.H. 1984. Biostatistical analysis. Prentice Hall, Upper Saddle River, N.J. 